\title{
PROSES BERNALAR SISWA DALAM MENGERJAKAN SOAL-SOAL OPERASI BILANGAN DENGAN SOAL MATEMATIKA REALISTIK
}

\author{
Suherman \\ Dosen Pendidikan Matematika \\ STKIP Muhammadiyah Pringsewu Lampung \\ Email:suherman_alghifari@yahoo.co.id
}

\begin{abstract}
Abstrak. Matematika memiliki peran yang sangat penting dalam membangun kemampuan berpikir dan berlogika siswa. Proses bernalar siswa terutama pada tingkat sekolah dasar masih rendah. Salah satu faktornya adalah belum menekankan pada pengembangan daya nalar (reasoning), logika dan proses berpikir siswa. Pengajaran matematika umumnya didominasi oleh pengenalan rumus-rumus serta konsep-konsep secara verbal, tanpa ada perhatian yang cukup terhadap pemahaman siswa. Penelitian ini bertujuan untuk mengetahui proses bernalar siswa dalam mengerjkan soal-soal operasi bilangan. Populasi pada siswa kelas IV SD Pucangsawit 79 Jebres Surakarta tahun pelajaran 2010/2011, dengan sampel sebanyak 4 orang. Hasil penelitian bahwa siswa masih mengalami kesulitan dalam menyelesaikan soal-soal tantangan yang menuntut kemampuan bernalar; siswa kurang kreatif dalam menyusun langkah atau strategi dalam penyelesaiannya; siswa belum optimal dalam memberikan ide-idenya pada soal yang menuntut kemampuan siswa untuk memberikan gagasan atau ide dalam bentuk alasan pada jawaban.
\end{abstract}

Kata Kunci: Proses Bernalar, Matematika Realistik

\section{PENDAHULUAN}

Matematika memiliki peran yang sangat penting dalam membangun kemampuan berpikir dan berlogika siswa. Fakta menunjukkan bahwa kedudukan matematika dalam cabang ilmu pengetahuan berada pada posisi yang tinggi, karena matematika akan mendasari kemampuan pemahaman atau berpikir seorang siswa pada mata pelajaran yang lain. Beberapa pakar matematika menyebutkan matematika sebagai "ratu" dari segala ilmu pengetahuan (Tarmidi, 2006), karena tidak dapat dipungkiri bahwa matematika sangat lekat dan selalu muncul dalam setiap aktivitas kehidupan manusia.

Namun, konsep matematika yang dimiliki oleh seorang siswa bukanlah satu-satunya faktor penentu pendukung dari ilmu pengetahuan (Nizar, 2008).
Hal terpenting adalah bagaimana membentuk pola pikir yang matematis dimana siswa tidak hanya menguasai konsep matematika, tetapi siswa mempunyai penalaran matematika. Hal tersebut juga sejalan dengan pernyataan sebuah lembaga penelitian di Amerika Serikat NRC (National Research Council) yang menyebutkan bahwa kemampuan berpikir dan bernalar jauh dibutuhkan di masa kini dan di masa yang akan datang (1989: 1).

Proses bernalar siswa terutama pada tingkat sekolah dasar masih rendah. Satu faktor penyebabnya adalah masih rendahnya kesadaran para pendidik matematika untuk merangsang dan menggali kemampuan bernalar pada siswa (Nizar, 2008). Orientasi dan tolok ukur yang masih dipakai oleh para pendidik dalam menentukan keberhasilan pembelajaran, masih 
sepenuhnya mengacu pada nilai yang diperoleh para siswa setelah diberikan soal atau ulangan setelah materi selesai. Padahal seharusnya dalam pembelajaran matematika pemecahan masalah menjadi fokus utama (Depdiknas, 2006). Oleh karena itu hendaknya para pendidik berani untuk bereksperimen dengan memberikan masalah-masalah untuk merangsang kemampuan bernalar siswa.

Berdasarkan hasil wawancara dengan guru SD diperoleh informasi bahwa dalam praktik pembelajaran matematika di kelas seringkali guru dihadapkan pada kenyataan bahwa sebagian besar siswa mengalami kesulitan dalam menyelesaikan soal operasi hitung, terlebih soal cerita, siswa tidak berani menanyakan hal yang menjadi kesulitannya dalam belajar matematika, pelajaran matematika dan khususnya soal cerita matematika bagi sebagian besar siswa merupakan hal yang menakutkan, jarang ditemukan ideide baru dari siswa dalam menyelesaikan soal operasi hitung dan soal cerita matematika, serta bagi beberapa guru merancang dan memilih masalah matematika yang kontekstual masih merupakan hal yang sulit.

Menurut guru di kelas tinggi kelas IV, masalah yang terkait dengan soal hitung telah dialami siswa sejak mereka duduk di kelas rendah (kelas I, II, dan

\section{PEMBAHASAN}

Pola Kemampuan Bernalar Siswa dalam

Menyelesaikan Operasi Hitung.

Soal penalaran tipe pertama
III). Hal ini selain disebabkan oleh keadaan di mana pada waktu kelas I dan II, soal operasi hitung tidak dibuat kontekstual dengan menggunakan benda-benda di sekitar siswa dan soal masih dibacakan oleh guru. Siswa belum mampu diajak berpikir abstrak dan pemahaman dalam membaca masih sangat kurang. Ini berarti dengan adanya kenyataan-kenyataan tersebut bagi siswa kelas tinggi, ketidakmampuan menyelesaikan soal matematika telah berlangsung dalam kurun waktu yang relatif lama. Selanjutnya terungkap bahwa secara umum letak kesulitan siswa dalam menyelesaikan soal matematika adalah menemukan bentuk operasi bilangan yang harus digunakan, dalam hal ini cara atau metode dan beberapa siswa mengalami kesulitan dalam menalar bentuk soal karena kurang pemahaman dalam membaca dan intonasi membaca.

\section{RUMUSAN MASALAH}

Bagaimanakah proses bernalar siswa dalam mengerjakan soal-soal operasi bilangan dengan soal matematika realistik?

\section{TUJUAN}

Untuk mengetahui proses bernalar siswa dalam mengerjakan soal-soal operasi bilangan dengan soal matematika realistik.

Wawancara, Untuk mengetahui prosedur yang dilakukan subyek (S) diberikan petikan wawancara oleh peneliti (P) sebagai berikut:

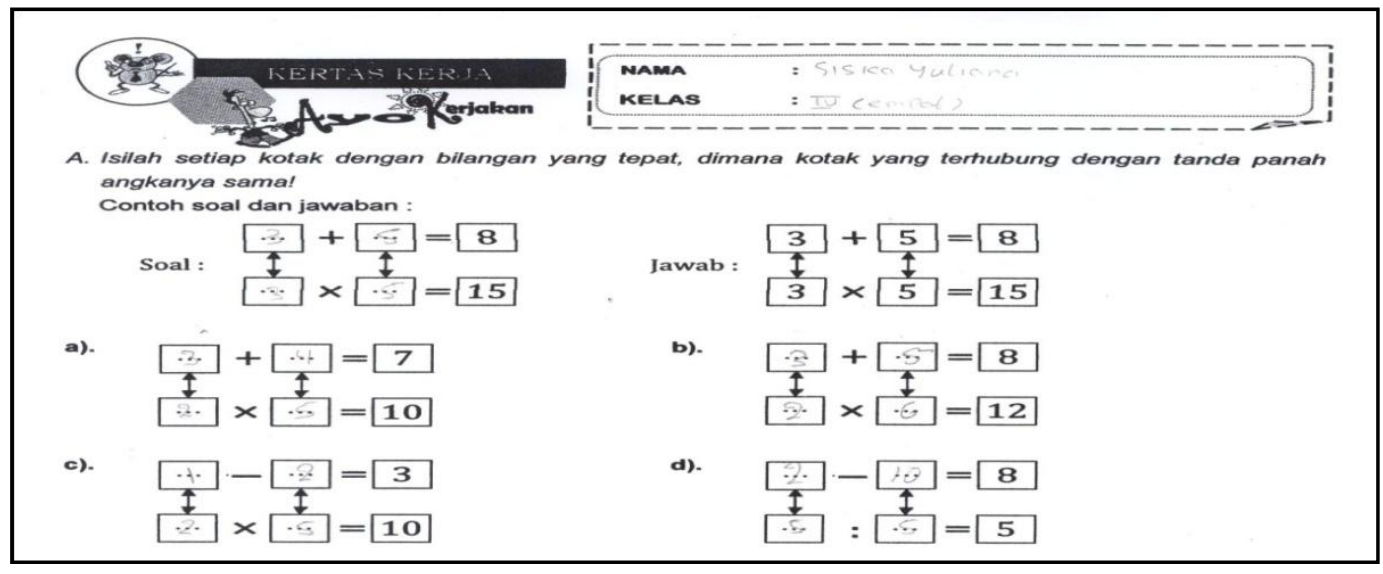


P : "Coba dibaca baik-baik soal nomor

A". Dan perintah soal a), b), c) dan d).

$S$ : (membaca soal)

P : "Bisa mengerti soalnya? Apa yang

diketahui dalam soal itu, Siska?"

$\mathrm{S}$ : "Bisa pak, diketahui jawaban yang tersedia dalam kotak"

P : "Bagus, sekarang coba untuk soal (a)

cari 2 bilangan yang jika ditambah hasilnya 7 dan jika dikali hasilny

10 "

$\mathrm{S}$ : (menghitung dikertas lain, dengan membuat coret-coretan). "sudah pak, untuk angka 7 saya dapatkan 3 dan 4 sedangkan untuk 10 saya dapatkan 2 dan 5 "

P : "sekarang coba yang jawaban (b),

(c), dan (d).

$\mathrm{S}$ : (siswa mulai menghitung). Sudah

Pak.

P : "ok, bagaimana jawabanmu"

$\mathrm{S}$ : "begini pak, untuk yang jawaban

(b) saya dapat angka 3 dan 5 untuk hasil jumlah $=8$. Sedangkan untuk jawaban yang hasl kalinya 12 saya dapat angka 2 dan 6.

(c) saya dapat angka 1 dan 2 untuk hasil pengurangan $=3$. Sedangkan untuk jawaban yang hasil kalinya 10 saya dapat angka 2 dan 5.

(d) untuk hasil pengurangan yang hasilnya 8 adalah 2 dan 10 . Sedangkan untuk pembagian yang hasilnya 5

adalah 5 dan 5 .

P : "Bagus, coba sekarang diletakkan

didalam tanda kotak

$\mathrm{S}$ : (meletakkan 2 buah bilangan

kedalam kotak)

P : "Bagaimana?"

S : "sudah pak"

P : "Oke, Sudah dicek dengan

operasiny?"

S : "sudah pak"

P : "coba hitung kembali"

$\mathrm{S}$ : "mengerjakannya dengan sedikit

kebingungan". Betul kok Pak.

P : "coba untuk jawaban (c), kamu dapat

dari mana?

S : "begini pak". Kan $3-2$ hasilnya 1

pak, dan 2 x 5 hasilnya 10 . Sedangkan
8.

untuk yang (d) kan 10 - 2 hasilnya

P : "Oke, tidak apa-apa"

Jika melihat hasil dari jawaban tersebut maka terlihat siswa sudah berusaha untuk menemukan jawaban dengan menuliskan berbagai macam kemungkinan angka agar menghasilkan jawaban yang benar. Siswa sudah melakukan percobaan pada bilanganbilangan yang ia pilih.

Dari hasil analisis pekerjaan siswa, pola jawaban pada abjad:

a. Pola penalaran sudah tepat dengan menuliskan angka pada kolom jawaban sehingga terbentuk proses jawaban yang benar. Yaitu $3+4=7$ dan 2 × $5=10$. Namun ketika ditempatkan pada kotak isian, maka isian tidak sesuai dengan permintaan soal, dimana angka yang diminta harus sama pada tanda panah. Penulis menduga, siswa tersebut tidak melakukan pengecekan kembali terhadap jawaban yang sudah diisikan. Sehingga siswa belum teliti dalam membaca perintah soal.

b. Pola penalaran point $\mathrm{b}$ sama dengan point a. Yaitu $3+5=8$ dan $2 \times 6=$ 12. Sehingga menghasilkan jawaban yang benar pula, hanya saja siswa belum memahami dengan teliti perintah soal.

c. Pola penalaran ponit c, yaitu siswa menuliskan $1-2=3$ dan $2 \times 5=10$. Siswa menduga bahwa jika $3-2=$ 1. Jawaban ini benar jika siswa mengerjakan dari prosedur belakang, tapi siswa tidak mengecek jika pekerjaanya dikerjakan dengan prosedur depan yaitu $1-2=3$.

d. Pola penalaran point d, yaitu siswa menuliskan $2-10=8$ dan $5: 5=5$. Hal ini bahwa siswa mengurangkan dari belakang terlebih dahulu yaitu $10-8=2$. Tetapi jika dari depan 2 $-10=8$, akan menghasilkan jawaban yang salah. Begitu pula dengan jawaban $5: 5=5$. Siswa mengerjakannya tidak dengan 
serius, karena terges-gesa, sehingga tidak sempat mengecek jawabannya.

Ini menunjukkan siswa kurang tepat dalam menempatkan angka pada kotak yang tersedia dan tidak melihat operasi yang tersedia, pada dasarnya untuk proses soal point (a) dan (b) sudah benar, namun ketika siswa meletakkan angka-angka dalam kotak yang terhubung dengan tanda panah, siswa tidak mengecek kembali perintah soal. Sehingga menyebabkan proses penalara soal yang diminta tidak tepat. Tetapi berbeda dengan point (c) dan (d), siswa mengerjakannya dengan prosedur terbalik, bahkan siswa juga mengisinya dengan tergesa-gesa karena melihat beberapa temannya ada yang sudah selesai.

Jika dikaitkan dengan langkah Polya dalam penyelesaian soal matematis, Jawaban sicwa nada soal tine B.

$$
\begin{array}{r}
\text { c).72 } \\
5(3) \\
21
\end{array}
$$

maka siswa belum memeriksa kembali prosedur dan hasil penyelesaian kegiatan menganalisis dan mengevaluasi apakah prosedur yang diterapkan dan hasil yang diperoleh benar. Hal ini karena siswa tidak berupaya untuk melakukan evaluasi terhadap jawaban yang diberikan apakah memenuhi pertanyaan atau tidak.

\section{a) Soal penalaran tipe kedua}

Melalui soal tipe ini penulis ingin mengetahui bagaimana anak menyelesaikan persoalan pada operasi penjumlahan, pengurangan, dan perkalian. Soal yang diberikan adalah tipe B yang terdiri dari lima soal. Penulis mengambil jawaban soal tipe B yang siswa mengalami banyak kesalahan yaitu jawaban soal B.c dan soal B.e. Berikut jawaban dari siswa Widat Ainir Rohmah.

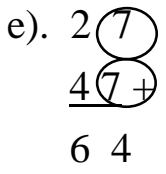

"benar tidak kamu meletakkan angka 2 di isian tersebut"

$\mathrm{S}$ : "saya bingung pak"

$\mathrm{P}$ : "coba dengan jawabanmu yang no e,
Wawancara

P : "Bagaimana Rohmah dengan pekerjaanmu nomor B ?"

S : "Salah Pak"
B. Gantilah setiap lambang asterik ( ") pada soal di bawah ini dengan angka 0-9 sehingga didapat penjumlahan, pengurangan, perkalian, ataupun pembagian yang benar!
a). 23
b). 245
c). 72
d). 638
$\frac{2}{40}+$
$434+$

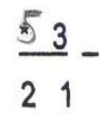
$223-$
e). 27

$$
679 \quad 21
$$

P : "Apa jawabanmu, coba dilihat"

$S$ : (menunjukkan jawabannya)

P : "Dari mana Rohmah bisa dijelaskan ?"

S : "Pertama, untuk jawaban c dikurangkan 7 dengan 5 hasilnya kan 2,

dan 3 dikurangkan dengan 2 hasilnya kan 1 pak.

$P$ : "coba di hitung lagi yang pengurangan 3 dikurang 2 hasilnya 1?" bagaimana kamu mendapatkan bilangan tersebut dan menjumlahkannya"

S : "pertama saya cari bilangan yang bisa ditambahkan dengan 7 dan haslnya 4, maka saya dapat angka 7.

Selanjutnya saya cari angka yang ditambahkan dengan 2 hasilnya 4 , dan saya dapat angka 2.

P : "kamu benar, tapi ada yang kamu belum lakukan, yaitu menyimpan 
angka

puluhan

dan

menambahkannya dilajur depan"

S : "ya pak, saya tahu itu, tapi punyaku bener kok pak"

Berdasarkan jawaban siswa pada soal B.c tersebut dapat dilihat anak belum menguasai konsep pengurangan pada soal yang disajikan dalam bentuk yang telah dimodifikasi. Untuk menyelesaikan soal B.c tersebut memang tidak memakai prosedur yang rutin, akan tetapi tetap memakai konsep pengurangan sebagaimana prosedur rutin dimana dimulai dari bilangan di sebelah kiri. Jawaban siswa pada soal B.c yaitu 2. Soal tersebut dapat dituliskan dalam kalimat matematika sebagai berikut.

$$
\ldots-3=1
$$

Ini menunjukkan bahwa siswa harus mencari angka yang jika dikurangkan dengan 3 akan menghasilkan angka 1. Berdasarkan hasil siswa, siswa mengalami kesulitan dalam menemukan angka yang jika dikurangkan dengan 3 menghasilkan 1 . Pada akhirnya siswa memaksakan operasi dalam soal tersebut menjadi pengurangan antara $3-2=1$

Pada soal tipe B.e pada lajur b ini siswa sudah mampu berpikir yang logis terkait dengan alasan yang diberikan. Akan tetapi soal tersebut tidaklah berdiri sendiri. Dengan demikian dapat dikatakan bahwa siswa belum mampu untuk menemukan sebuah hubungan antarmasalah dalam soal. Ini dapat dilihat dari hasil penyelesaian soal dari siswa yang menunjukkan siswa cenderung melihat persoalan per lajur, tanpa mengaitkan dengan lajur yang lain dalam soal tersebut. Akibatnya solusi yang diberikan siswa hanya memenuhi satu lajur saja.
Berdasarkan jawaban soal B.e tersebut terlihat bahwa sebenarnya siswa sudah mampu menemukan sebagian besar bilangan dengan benar, akan tetapi masih terdapat kesalahan pada penyelesaian lajur depannya. Untuk menemukan bilangan dengan mengganti tanda asterisk ( $*$ ) dalam soal tersebut maka siswa dituntut untuk berpikir kritis dengan terlebih dahulu memahami konsep penjumlahan bilangan dua angka dengan bilangan dua angka, sehingga yang diinginkan penulis melalui soal ini adalah bagaimana seorang siswa menyelesaikan soal melalui prosedur yang tidak rutin tetapi masih menggunakan konsep penjumlahan bilangan dua angka dengan bilangan dua angka.

Dengan melihat jawaban siswa di atas, siswa mengalami kesalahan prosedural dalam penjumlahan bilangan dua angka dengan dua angka. Untuk mendapatkan jawaban, maka prosedur yang benar adalah bagaimana memperoleh bilangan yang jika dijumlahkan dengan bilangan 7 akan menghasilkan bilangan 4. Jika ditulis dalam bentuk matematika adalah

$$
7+\ldots=4 \text {. }
$$

Maka bilangan yang tepat untuk mengisi titik-titik tersebut adalah angka 7 . Selanjutnya, untuk lajur depan siswa menjumlahkan dengan prosedur

$$
2+\ldots=4 \text {. }
$$

Maka jawaban siswa adalah 4. Tanpa memperhatikan bahwa pada lajur kiri siswa harus menyimpan angka puluhan yaitu 1 , sehingga angka 1 tersebut untuk menambahkan jawaban pada lajur depan.

Berikut jawaban siswa yang bernama Lidya Wulan Valentina.

B. Gantilah setiap lambang asterik ( ") pada soal di bawah ini dengan angka 0-9 sehingga didapat penjumlahan, pengurangan, perkalian, ataupun permbagian yang benar!
a). 22
b). 245
c). 72
d). $6 * 2$
e). 22 
Dari hasil jawaban tersebut, pada point $\mathrm{c}$ d, dan e mengalami kesulitan dalam mengerjakannya. Pada point $\mathrm{c}$ terlihat bahwa

$$
\ldots-3=1
$$

\section{Wawancara}

$\mathrm{P}$ : "Bagaimana Lidya dengan pekerjaanmu nomor B ?"

S : "Salah Pak"

P : "Apa jawabanmu, coba dilihat"

$\mathrm{S}$ : (menunjukkan jawabannya)

P : "Dari mana Lidya, bisa dijelaskan ?"

S : "Pertama, untuk jawaban (e) kan 7 x

2 hasilnya 14 , saya tulis 4 dan

menyimpan angka 1, lalu saya tambahan dengan $2+3+1=6$. Sedangkan untuk

jawaban (d) kan 5 -3=2, 2-1=1 dan 6-2=4. Untuk jawaban (c) 3-2=1 dan

$7-5=2$. Dan untuk jawaban (a) $2 \times 3=6$ dan $2+2=4$

P : "coba di hitung lagi, dan perhatikan tanda operasinya ya".

S : "iya pak, tapi terkadang saya juga tidak bisa pak".

Hal ini terlihat bahwa dalam bernalar, siswa belum mampu mengurangkan seperti soal di atas, sehingga siswa terkadang mengerjakanya dengan

\section{Soal C}

operasi terbalik, misalnya: $3-2=1$. Pun sama dengan pont $\mathrm{d}$ dan point e.

Jika dikaitkan dengan langkah Polya, maka siswa mempunyai kelemahan pada langkah perencanaan soal sehingga menyebabkan kesalahan pada langkah berikutnya yang pada akhirnya siswa memperoleh jawaban yang salah. Adanya kesalahan yang dilakukan siswa pada langkah tersebut, menunjukkan siswa be-lum matang dalam konsep penjumlahan bilangan puluhan. Sehingga seorang guru harus benar-benar mematangkan konsep penjumlahan puluhan terutama pada penjumlahan bilangan dua angka dengan bilangan dua angka.

\section{b) Soal penalaran tipe ketiga}

Melalui soal tipe ketiga ini penulis menginginkan siswa untuk memberikan alasan pada jawaban yang mereka berikan. Ini berkaitan dengan kemampuan anak untuk menyampaikan ide dan gagasan yang mereka miliki sebagai bagian dari kemampuan bernalar siswa. Oleh karenanya, soal ini penulis berikan kepada anak yang memiliki kemampuan lebih tinggi daripada tipe A atau B.

Berikut adalah jawaban siswa yang bernama Widat Ainir Rohmah.

Dibawah ini terdapat jawaban dari soal. Benar atau salahkah jawabannya dan berikan alasanmu! Ibu mempunyai 75 ekor ayam. Ayam-ayam tersebut akan dimasukkan ke dalam 5 buah kandang. Berapa banyak ayam setiap kandangnya? Jawabannya : 70 ekor ayam Benar atau salah jawaban tersebut? .................

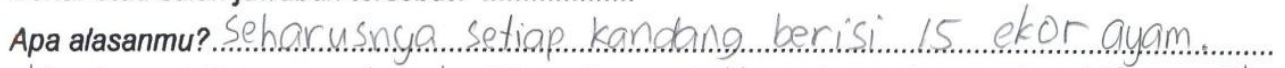

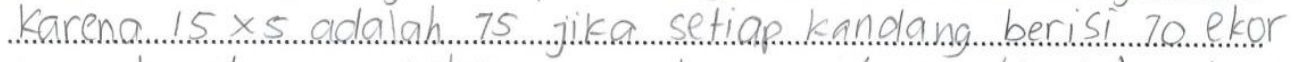
ayam kandangnya cehar y smy. hany ado 2 atau k kandang Sarian. 
Soal D

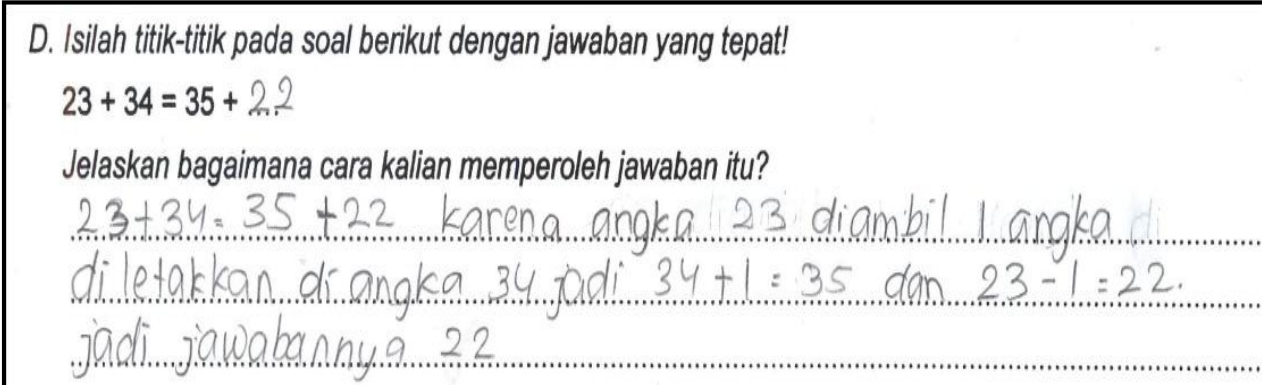

Pada soal C yang diberikan,
penulis memang menuliskan kata "sama banyak" setelah kata kandang karena penulis menginginkan adanya pemahaman atau interpretasi anak yang berbeda-beda terhadap soal sehingga memunculkan jawaban yang bervariasi. Soal ini dapat diselesaikan dengan prosedur rutin jika pemahaman anak dibagi dengan sama banyak. Dengan melihat jawaban siswa di atas maka dapat diketahui bahwa anak telah dapat meng-ungkapkan gagasan dan idenya dalam bentuk alasan pada jawaban yang diberikan. Ini menunjukkan pada soal yang dapat diselesaikan dengan prosedur rutin, siswa tidak terlalu sulit untuk menyampaikan ide atau gagasan yang berupa alasan pada jawaban yang diberikan.

Dari hasil jawaban siswa diketahui bahwa siswa menyatakan "salah" terhadap jawaban soal, dan siswa menyatakan jawabannya dengan "seharusnya setiap kandang berisi 15 ekor ayam, karena $15 \times 5$ adalah 75,

$$
22+\underset{\text { Sama }}{35=35}+\mathbf{2 2}
$$

Dengan melihat pada kedua ruas terdapat bilangan yang sama yaitu 35 , maka akan dengan mudah mendapatkan bilangan yang tepat untuk mengisi titik-

$$
23+34=35+\ldots
$$

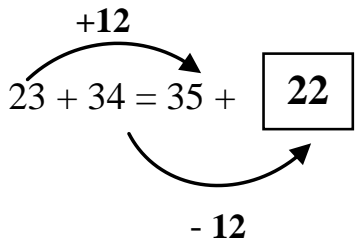

jika setiap kandang berisi 70 ekor ayam kandangnya seharusnya hanya ada 2 atau 1 kandang saja”. Siswa tidak memiliki anggapan bahwa langkah yang benar adalah 75 ekor ayam dibagi 5 dan bersisa 5, karena menurut siswa tersebut kalau tidak ada kata "sama banyaknya" maka isi dari tiap kandang tidak harus sama. Jadi menurut siswa jika 10 dibagi 2 jika tidak ada kata "sama banyaknya", maka hasilnya tidak harus sama dengan 5. Jawaban yang mungkin misalnya 6 dan 4 .

Untuk soal tipe $\mathrm{D}$, penulis ingin mengetahui apakah anak bisa berpikir kreatif untuk menyelesaiakan soal yang diberikan. Dengan berpikir kreatif, soal tipe D tersebut sangat mudah untuk diselesaikan. Berikut ini langkah kreatif yang dimaksud oleh penulis. Dari soal diperoleh kalimat matematika:

$$
23+34=35+\ldots
$$

Pada ruas kiri, jika 23 diambil 1 dan kemudian 1 yang diambil dari 23 ditambahkan pada bilangan 34, maka kalimat matematikanya akan menjadi sebagai berikut:

titik tersebut. Bilangan yang memenuhi titik tersebut adalah 22. Atau dengan langkah yang lain seperti berikut ini. Dari soal diperoleh kalimat matematika: 
Pada ruas kiri, bilangan 23 untuk menjadi 35 maka harus ditambah 12. Karena merupakan persamaan matematika, maka agar ruas kanan tetap sama dengan ruas kiri, bilangan 34 harus dikurangi 12. Dengan mudah diperoleh jawaban bilangan 22 yang merupakan hasil dari $34-12$. Langkah atau cara yang lain masih dapat ditemukan untuk menemukan jawaban yang benar.

Dengan melihat jawaban siswa di atas, maka diketahui siswa sudah mampu berpikir kreatif untuk menemukan solusi jawaban yang tepat dengan cara yang cepat dan mudah seperti yang penulis inginkan. Dari jawaban siswa yang bersangkutan, bahwa untuk mendapatkan jawaban tersebut siswa terlebih dahulu menyelesaikan dengan " $23+34=35+$ 22 karena angka 23 diambil 1 angka diletakkan diangka 34 jadi $34+1=35$ dan $23-1=22$ jadi jawabannya 22". Dengan demikian langkah penyelesaian masalah yang digunakan siswa memerlukan waktu yang relatif lama, meskipun pada akhirnya siswa juga menemukan jawaban yang benar seperti yang penulis inginkan.

Pada jawaban soal D terlihat siswa juga sudah mampu memberikan alasan terhadap jawaban yang mereka berikan, meskipun struktur bahasa yang dipakai belum baik. Dari hasil wawancara dengan siswa, bahwa siswa mengalami kesulitan untuk menyampaikan alasan yang diberikan. Hal ini terlihat juga ketika siswa mengerjakan soal dimana siswa mengalami kesulitan untuk memberikan alasan atau cara mendapatkan jawaban, meskipun siswa sudah mendapatkan jawabannya. Ini menunjukkan pada soal yang menggunakan prosedur non-rutin, siswa masih mengalami kesulitan untuk menyapaikan ide atau gagasan mereka yang berupa alasan terhadap jawaban yang mereka berikan.

Kesulitan dalam soal cerita tipe C dan D bagi siswa sebenarnya terdeskripsi dalam beberapa hal berikut: a. Siswa dengan pemahaman bahasa rendah, sangat sulit mencerna arah tujuan dari tiap kalimat pada soal cerita;

b. Pemahaman konsep matematika yang rendah, menyebabkan siswa sulit menentukan konsep mana yang harus digunakan dalam sebuah soal cerita. Hal ini karena biasanya siswa sudah terlebih dahulu terabstraksi dalam teori-teori dan rumus sehingga dalam penerapannya abstraksi siswa akan pecah dengan masalah baru yang dihadapi secara aplikatif;

c. Kurangnya pengalaman dalam mengonstruksi pola pikir juga termasuk kesulitan siswa. Siswa tidak terbiasa untuk menyelami soal-soal aplikatif yang berbau soal cerita;

d. Kesan negatif terhadap soal-soal cerita yang terlihat memiliki kalimat yang panjang sehingga siswa merasa malas bahkan tidak jarang merasa takut sebelum menyelesaikan soal tersebut;

e. Ceroboh dalam pengerjaan soal yang tercermin pada pengerjaan soal dengan terburu-buru.

Permasalahan pendidikan matematika berupa sulitnya menyelesaikan soal operasi hitung dan soal cerita tersebut dapat diminimalisir dengan menerapkan strategi pembelajaran yang berorientasi pada upaya bagi siswa untuk:

a) membangun sikap dan persepsi positif terhadap belajar dan terhadap matematika sebagai obyek belajar;

b) memperoleh dan mengintegrasikan pengetahuan matematika;

c) memperluas (mengembangkan) dan memperbaiki pengetahuan matematika yang telah dimiliki;

d) mampu menggunakan pengetahuan matematika yang dimiliki baik dalam belajar matematika, ilmuilmu lain, maupun dalam kehidupan sehari-hari; 
e) membangun kebiasaan berfikir produktif;

f) menggunakan pembelajaran yang bersifat kooperatif.

\section{SIMPULAN}

Berdasarkan pembahasan hasil penelitian disimpulkan bahwa:

1. siswa masih mengalami kesulitan dalam menyelesaikan soal-soal tantangan yang menuntut kemampuan bernalar;

2. siswa kurang kreatif dalam menyusun langkah atau strategi dalam penyelesaiannya;

3. siswa mengalami kesulitan pada operasi hitung, sehingga terkadang operasi pada soal dikerjakan terbalik (tidak sesuai perintah);

4. siswa belum optimal dalam memberikan ide-idenya pada soal yang menuntut kemampuan siswa untuk memberikan gagasan atau ide dalam bentuk alasan pada jawaban.

\section{DAFTAR PUSTAKA}

Ahmad Nizar. 2008. Kontribusi matematika dalam membangun daya nalar dan kemampuan komunikasi siswa. Jurnal Pendidikan Inovatif Vol. 2 Nomor 2, Maret Tahun 2007.

Depdiknas. 2006. Kurikulum Tingkat Satuan Pendidikan SMA. Tersedia online pada http://www.puskur.co.id. Diakses tanggal 12 November 2010.

NRC (National Research Council). 1989.

Johnson, E. B. 2009. Contextual Teaching and Learning. Bandung: Mizan Learning Center
Ruseffendi, E.T. (1991). Pengantar kepada Membantu Guru Mengembangkan

Kompetensinya dalam Pengajaran Matematika untuk Meningkatkan CBSA. Bandung: Tarsito.

Soedjadi, R. dkk. 1996. Penelitian Kualitatif (Pengertian dan Dasar Teori, Metode, Desain dan Contoh). Makalah PPs IKIP Surabaya.

Suherman, E. dan Sukjaya, Y. (1990). Petunjuk Praktis untuk Melaksanakan Evaluasi Pendidikan Matematika. Bandung: Wijayakusumah 157.

Sumarmo, U. (2003). Daya dan Disposisi Matematika: Apa, Mengapa dan Bagaimana Dikembangkan pada Siswa Sekolah Dasar dan Menengah. Makalah disajikan pada Seminar Sehari di Jurusan Matematika ITB, Oktober 2003.

Tarmidi, R. D. S. Matkita: Profil. Tersedia online pada www.matkita.com. Diakses tanggal 12 November 2010. 